\title{
The sanctuaries of the Rain God in the Mixtec Highlands, Mexico: a review from the present to the precolonial past
}

\author{
Liana Ivette Jiménez Osorio $^{1} \cdot$ Emmanuel Posselt Santoyo $^{1}$
}

Received: 29 February 2016/ Accepted: 28 July 2016/Published online: 5 December 2016

(C) The Author(s) 2016. This article is published with open access at Springerlink.com

\begin{abstract}
This article focuses on the sanctuaries of the Rain God through time, paying particular attention to the devastations and the consequences that these sacred places suffered due to the colonization carried out by the Spaniards in 1521 . The research refers to the cultural area of Mesoamerica, particularly the region of the Mixteca Alta in Oaxaca, Mexico. Vehe Savi (House of the Rain God) is the concept in mixtec language that refers to a sacred place where the indigenous communities perform rituals named "Bringing the Rain". As a result of the synergy between the Mesoamerican religion and the Christianity, the celebration of the ritual in the Vehe Savi (House of the Rain God) is part of the annual liturgical order of many communities in the Mixteca Alta. Records made by friars in colonial times tell us about the Houses of the Rain, from their perspective these sacred places were the houses of the demon, and they attached these with a negative symbolism. At the same time, interestingly, these colonial records show us the astonishment of the friars for these places that were uncommon for them. In such a way, this article integrates the knowledge and experiences of the Nuu Savi People, about the Vehe Savi (House of the Rain God), with descriptions that were written by the friars in colonial documents, and cultural manifestations from precolonial past such as ancient books (codices) and stone monuments, in order to talk about the historical depth of these sacred places and religious manifestations. The Vehe Savi and the ritual of Bringing the Rain are essential elements of the religion of the indigenous peoples in the Mixtec Highlands, but at the same time, the negative symbolism imposed during colonial period persists in many people with different background. For this reason, it is fundamental their recognition and respect as part of this multicultural world, where we belong as human beings.
\end{abstract}

Keywords Rain God - Sacred landscape $\cdot$ Peoples · Mixtec $\cdot$ Mixteca Alta $\cdot$ Mesoamerica

Liana Ivette Jiménez Osorio

lianaji@hotmail.com

Emmanuel Posselt Santoyo

eps537@hotmail.com

1 Faculty of Archaeology, Leiden University, Einsteinweg 2, 2333 CC Leiden, Netherlands 


\section{Introduction}

Water is an essential part of the world in which we live and as such has been incorporated in the worldview of different societies throughout history. Each society attributes to water a value and meaning of its own, forming a part of their identity. In this sense, the indigenous histories of water provide a specific understanding of this perspective, providing glimpse of the close relationship between living beings and this vital liquid.

Thus, this article focuses on the importance of the sanctuaries of the Rain God and its perception through time in $\tilde{N} u u S_{a v i}{ }^{1}$ (People of the Rain). This region known as Mixteca, includes the states of Oaxaca, Puebla and Guerrero, in southern Mexico, and is part of the cultural area of Mesoamerica (Fig. 1).

The relevance of the paper is to point out how the knowledge and the perception about water as a sacred being has been learned and experienced through time (since 3200 years ago approximately). This was a result of the continuous experience in these sacred places, despite of the different critical moments of the Mexican history. Currently, the sanctuaries of the Rain God and the experiences carried out in them are a significant part of the $\tilde{N} u u$ Savi and Mesoamerican heritage. This relationship with water proposes an understanding that goes beyond of its value as a resource, something important in a globalized era where water is being severely affected by pollution, inadequate use, and overexploitation.

The landscape of the communities of $\tilde{N} u u$ Savi is inhabited by various $\tilde{n} u h u$ (sacred beings) who are said to be in eternal coexistence with human beings, as the Sun, the Wind, the Grandmother of the Temazcal (steam bath), the Water, the Lady of the Spring, the Corn and the Rain, among others; they all have been present since ancient times.

It should be noted that, as of this writing, landscape is understood as a lasting record of the lives and works of past generations, which have inhabited it and in so doing have left something of themselves. It is also considered that the landscape is never completely built but in continuous transformation and through life becomes part of us as we become part of it. The landscape is the world as it is known by those who inhabit it, those who live in their places and travel along its paths that connect them. It is impregnated with personal skills and encompasses human beings, animals and plants, more than human beings, as well as the places in which all move and live (Ingold 2000).

In this way, the landscape is not a whole that anyone can look at. It is rather the world in which we stand in taking up a point of view on our surroundings. It is within the context of our participation in the landscape that human beings get to work in the configuration of ideas on it (Ingold 2000). The shapes that humans build, either in the imagination or on the ground, arise within the currents of our activity, in contexts of specific relations of a practical involvement with our surroundings (Ingold 2011). Therefore, the world is formed by the intersection of lines of life of different beings that are lines of growth and lines of movement, and covers both heaven and earth (Ingold 2011).

It should also be noted that this cosmos is polyglot, a mixture of voices by means of which different beings more than human (gods), in their various languages, announce their presence, are felt and have effects. To lead a life suitable to this thought, we must harmonize ourselves with those voices and listen and respond to what they are saying (Ingold 2013). This condition is relevant to our understanding of the sacred beings, within them the Rain God, which inhabit the landscape of a community.

\footnotetext{
1 This denomination in dzaha savi (Language of Rain) refers to the People of the Rain; at present is the most accepted by the speakers to refer in a general way to this region, although there are different words according to the dialectal variant. In the colonial era it was appointed Ñu Dzavui (Pérez 2008).
} 


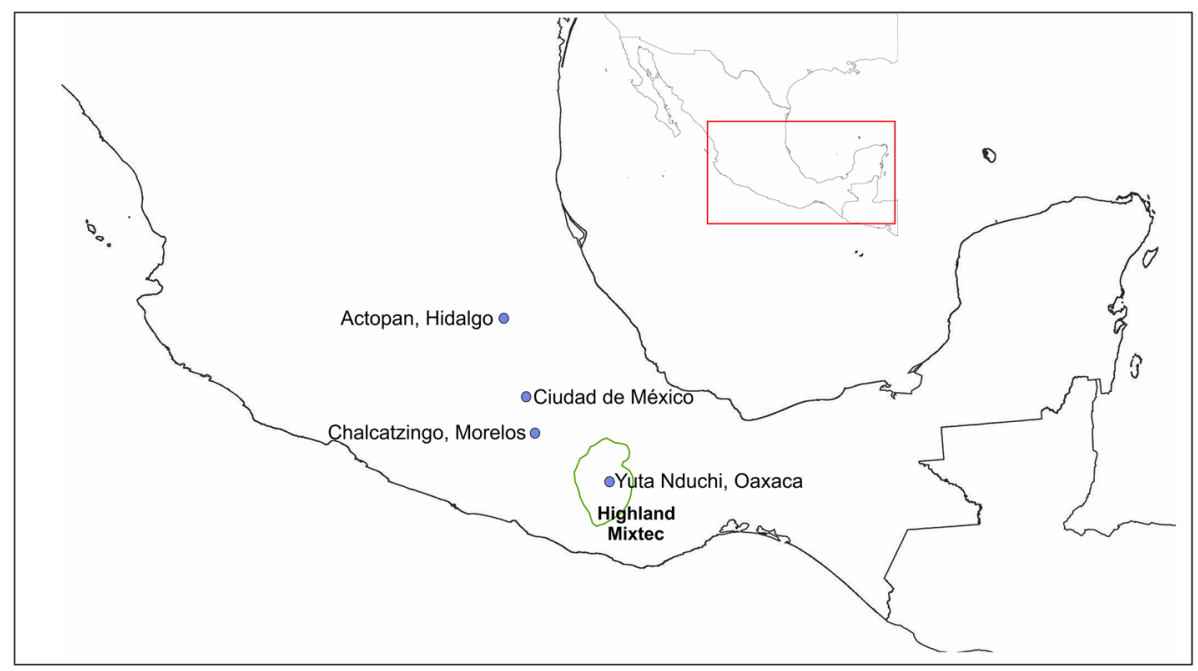

Fig. 1 Location of the communities referred to in the text

Focusing on the Rain God it is known that in precolonial times he was one of the main gods of the Peoples that integrated Mesoamerica. As in the past, today this god is relevant in the religion of the indigenous peoples of Mexico; in Mixtec language he is known as Savi. It should be noted that the name of the area of study in Mixtec, Nuu Savi (People of the Rain), indicates the importance of this divine being.

The dwellings of this god are the sacred places that are associated with water, such as caves, the top of mountains, rocks, springs or rocky shelters; the term for these is Vehe Savi (House of Rain God). These sanctuaries are part of the sacred landscape of each community; they perform rituals related to the rain and fertility in them, which are referred to as bringing the rain or requesting the rain. It is important to mention that, like the Rain God, the Vehe Savi were ichnographically represented since Olmec times (1500-500 B.C.).

History teaches us that the current perception of the Rain God and his dwellings as well as the ritual of bringing the rain is the result of the synergy between the Mesoamerican religion and Christianity, the latter imposed during the Spanish colonization in 1521.

Notwithstanding the importance of the rain in religion and in the landscape of the indigenous peoples currently, its conceptualization and perception are disqualified and rejected by people outside this tradition and by some of the inhabitants of the region itself, motivated by the generalized ideas of progress and an official religion promoted by the State.

This demeaning of Savi (Rain God) and the Vehe Savi (House of the Rain God) began in the colonial era, when it was decided to eliminate the Mesoamerican religion through the Spiritual Conquest. The first friars that arrived to this region described the sanctuaries of the Rain God, from their perspective these places were the dwellings of the devil and associated them with a negative symbolism. Nonetheless, these colonial records also reveal the astonishment the friars had in regard to these sacred places with which they were not familiar.

From that moment, the sacred terms to refer to the constituent elements of the Mesoamerican religion as sacred beings, sanctuaries, rituals, offerings, priests, practitioners, etc. were replaced with the demonizing characterizations of idolatry, witchcraft, 
sorcery, idols, demons, works and places of the devil, human sacrifice, idolaters, witches, etc. This shift radically transformed the experience, practice and constitution of the people practicing this religion, yet did not completely fulfill its objective of exterminating it.

Currently this colonial imaginary of the Mesoamerican religion and of those who exercised it, is reproduced in the academic field as it is reproduced in the ideas and terms of the colonizers in archaeological, historical and anthropological studies. This view is bereft of a critical sense and is remiss in acknowledging it as a living religion whose representation directly affects the identity and cultural heritage of the indigenous peoples of Mexico in general and of the Mixtec in particular.

To reinforce this last idea, we follow the guidelines of Professors Maarten Jansen and Gabina Aurora Perez in relation to what they called living archaeology (in the sense of a cultural continuity) and postcolonial hermeneutics. With these principles, current, colonial and archaeological data and documents are gathered for a better understanding of the precolonial history and with the interest of reconstructing old perceptions, revitalizing memories and developing cultural identities that have been interrupted, oppressed and cast into oblivion since the colonial period (Jansen 2004, 2008; Jansen and Pérez 2008, 2011).

Through this approach, Gabina Aurora Perez Jimenez from Nuu Ndeya (Town of Abundance) in the Mixteca Alta mentions:

The social transformation must go hand in hand with a change of perspective and attitude on the side of those who study our linguistic and cultural heritage; it is necessary to abandon a series of terms of the anthropological jargon and discriminatory views, such as "ethnic groups" or "minorities", because we are People with language, history, territory and dignity; we are Original Peoples, who have been in this land since it was discovered and inhabited by the first humans. There are many terms of the Spanish-speaking world and references to the Mexican nation that surround us, confuse us, make us invisible and, furthermore, offend us. They all seem to exclude us and continue a colonial practice of making us people without history and foreigners in our own land (2008).

In that way, this article presents a historical study of Savi (the Rain God) and the Vehe Savi (House of the Rain God) that takes as its point of departure the understanding and the experiences of the $\tilde{N} u u$ Savi, which are forged during the ritual of Bringing the Rain, which we learned through the active participation and engagement. ${ }^{2}$ Active participation is a fundamental point of our methodology for documentation and understanding of this ritual.

In short, the methodology that we use in this research is the integration of current, colonial and precolonial data and documents, through the landscape and living archaeology approaches that focus on the dwellers' perception in each historical moment. This in order to know the Nuu Savi People's understanding about water, and to smash the stigma created around this knowledge and their holders since colonial period.

We will begin with the description of this ritual, when the sacred character of the Vehe Savi is empowered and Savi manifests itself. Afterwards, a comparative analysis with some colonial and precolonial documents will be presented to understand the historical depth of the conceptualization of the Vehe Savi, showing continuities and changes over time. We chose this sequence from present to past and not the traditional one used in historical works

\footnotetext{
2 In this regard, it's important to clarify that in the description of the ritual, the use of "we" refers to our own participation as pilgrims during the ritual (active participants) and as authors of this paper, and this last one is always specified. Likewise, the speech in third person expose our condition as novices in the community.
} 
(from past to present) because we don't want to give interpretations from the precolonial data or from the colonial voices (colonial documents). Instead of this, we will start with the knowledge of the $\tilde{N} u u$ Savi People in order to positioning the indigenous peoples as makers and holders of this Mesoamerican cultural heritage.

\section{Ritual of bringing the rain in the Vehe Davu ${ }^{3}$ (House of the Rain God) of Yuta Nduchi}

The perception of water as different sacred beings that inhabit specific places in the landscape, in close interaction with living beings, has been shared by the different indigenous peoples of Mexico since ancient times (Méndez Granados 1999). In addition, from this understanding, water has a major influence on the life of the human beings that integrate a community; hence, the importance of knowing its qualities, the beings and the sacred ways in which it manifests itself, the sacred places it dwells and rituals for its commemoration.

The divine being to which we refer in this article is the Rain God. Coexistence with this being can occur in dreams and during the realization of the rituals. The ritual with which this divinity is currently commemorated is generally known as bringing the rain and due to its importance, is part of the annual liturgical order of several communities of Nuu Savi (People of the Rain) (Monaghan 1995; Barabas et al. 2010).

In $\tilde{N} u u$ Savi, the bringing the rain is carried out on a fixed date of the Gregorian calendar that varies from April 24 to May 15, according to the liturgical calendar of each community. This lapse of time corresponds with the celebration of various catholic saints: San Marcos (April 25), The Holy Cross (May 3) and San Isidro Labrador (May 15), which in some communities are known as Saints of the Rain. ${ }^{4}$

During the development of our research, we have participated in various rituals of bringing the rain allowing us to recognize their general structure, which we follow for the description in this section. The ritual that we present is part of the liturgical order of the community of Yuta Nduchi in Oaxaca, Yuta: river, Nduchi: beans, i.e. River of Beans, which is located in the central part of the Nuu Savi region (Fig. 1).

The liturgical order of this community is made up of 14 rituals that are held in a specific date throughout the year. Local residents, the wise ones ${ }^{5}$ and the authorities of the Catholic Church who are from the community organize these festivities. Rituals are celebrated in the church as well as in different natural sanctuaries within the community and its surroundings, which generates a multiplicity of places that are interwoven to shape a sacred landscape.

Using the aforementioned approach of landscape, emphasizing dweller perspectives and the search of knowledge through participation and personal experiences, the description of

\footnotetext{
3 The word Davu corresponds with Savi, both refer to Rain God in Mixtec Language. The first one is the dialectal variant of the community of Yuta Nduchi and we will use this for the description of the ritual.

4 It should be noticed that, as a result of the colonization, the most important festivities of the Mesoamerican religion were merged with the Christianity, and currently this synergy is experienced as one religion which is the basis for the liturgical order of the communities. Additionally, in the contemporary Mixtec communities the Church is guided by its own inhabitants most of the year, which allow the inclusion of different sacred places and rituals important for each community. In this sense, the Catholic Church, in some communities, is currently more flexible than as it was during colonial period.

5 This term refers to the persons, generally older, who are recognized by all the residents as the holders of the historical and ritual knowledge of the community.
} 
the ritual ${ }^{6}$ provided below is the result of a series of engagement and knowledge acquired among the inhabitants of Yuta Nduchi. We present a detailed description of the ritual because we want to highlight its sacred aspect as part of a millenary religion and because the experience in the landscape, precisely, gives us a greater understanding of the sacred beings and places.

In this community, the ritual of bringing the rain is performed every year on May 1, its structure and the sequence of the different acts that comprise it have been learned over time due to the involvement and commitment of the participants that lead to its continuous reestablishment. During this ritual, one has the experience of sharing the same space-time and being a member of the same community, which gathers and lives for a common good, namely the rain and a good harvest.

The sacred places where these rituals are performed are the Vehe Davu (House of the Rain $\operatorname{God}^{7}$ ), it should be noted that its own configuration given by different millenary processes inspires admiration, beauty and respect, feelings that are going to affect the condition of each participant and the congregation as a whole.

All the Houses are enormous and have different formations as well as small caves or niches; many are caves of great depth and a game of darkness and light is generated in their interior, creating a sacred atmosphere together with the smoke of copal and the sound produced by the drops sprouting from its own roof; some have rocky walls rich in minerals that project a great brightness with the sunrays.

In Yuta Nduchi there are four Vehe Davu whose location corresponds to the four directions. ${ }^{8}$ The Vehe Davu from the northeast is a rock shelter, the one from the southeast is a large cave, the one from the southwest is formed by a rock that gives the appearance of two large rocks placed upon one another, and finally the Vehe Davu from the west is a rock shelter that is part of a ravine. We also consider that, on this feast day, the Catholic Church located in the center of the population is another Vehe Davu ${ }^{9}$ where Ihtoro Davu (our Rain Lord) is commemorated, in this sense it can be said that there are five Houses of the Rain God (Fig. 2).

The four Vehe Davu located in the surroundings of the community are visited on the same day by the people benefiting from the water associated with one of them, that is to say, their farm land, or the fruits that the Earth god provides in its proximity. The ritual is directed by a marduma davu (head for the celebration to the Rain God) who has voluntarily chosen to visit a particular House of the Rain God and offer to Davu (the Rain God) on this date for seven consecutive years.

\footnotetext{
${ }^{6}$ For the present article we use the principles enunciated by Rappaport (2001) that define the ritual as: the implementation of more or less unchanged sequences of formal acts and expressions not fully encoded by the performers, which logically implies the establishment of a convention. It should also be noted that the guidelines that this author sets for the understanding of the ritual focus on the experience of the same, in what you experience at individual and communal level; in this sense he also refers that the definition he provides of ritual is neither substantive nor functional, but gives more importance to the sensitive features, common to rituals of all places and times, features that help to recognize certain events as rituals.

7 From here onwards the word Rain makes reference to the divinity and the House or Houses are understood as its dwellings, so, its use implies a connotation of sacredness.

8 The number of the Vehe Davu is different in each community; there are communities with only one or two Houses while others have 13 or more Houses, as Mitlatongo-neighboring community of Yuta Nduchi(Barabas et al. 2010). In the region of Nuyoo there are four Houses of Rain whose location also corresponds with the four cardinal points (Monaghan 1995).

${ }^{9}$ In a general way, all the sacred places are appointed Vehe $\tilde{N} u h u$ (House of God).
} 


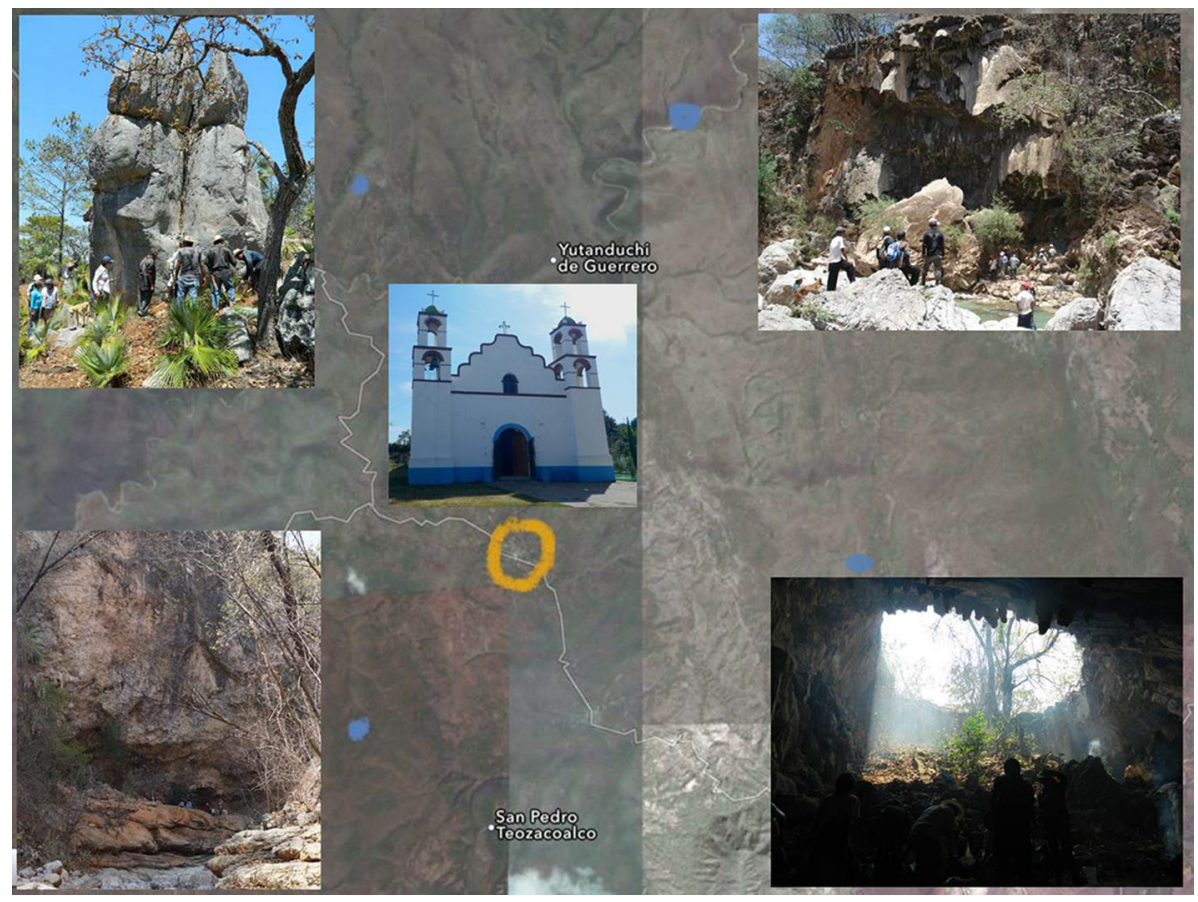

Fig. 2 The five Houses of Rain in Yuta Nduchi, Oaxaca

The ritual is performed during 2 days; on April 30, the authorities of the church place Ihtoro Davu (our Rain Lord) in front of the altar, and the population offers prayers throughout the night. On the morning of the next day, at the same time that the pilgrimages depart toward the four Vehe Davu, the authorities of the church lead Ihtoro Davu in procession through the streets of the town. It is important to note that, within the catholic canons, this image is part of the Holy Trinity (the Father, the Son and the Holy Spirit), it is the Son, and has been appropriated and reinterpreted by the community as Ihtoro Davu (our Rain Lord).

The pilgrimages to the Vehe Davu depart from the house of every marduma Davu (head for the celebration to the Rain god); they are long walks, the shorter is approximately two and a half hours and the longest lasts about $5 \mathrm{~h}$, not to mention that each route has its own significant places.

When we finally arrive at the sacred place, there is a shared feeling of happiness in being there; we then proceed to ask permission of Davu (the Rain God) to pass to its Vehe (House) and perform the offerings and promises. This is done with an offering of beverage (mescal is poured before entering to the House) as a way to indicate that we are entering into a sacred place.

Subsequently, a fire is made using burning coal to burn copal and, as such, the place is smoked, a cleaning is also performed, and the direction the Rain must follow to reach out to the community is indicated with bouquets of flowers. With these actions, a sacred atmosphere is created and at that time the divinity is present; it is Davu (the Rain God) who announces how the next rainy season will be. 


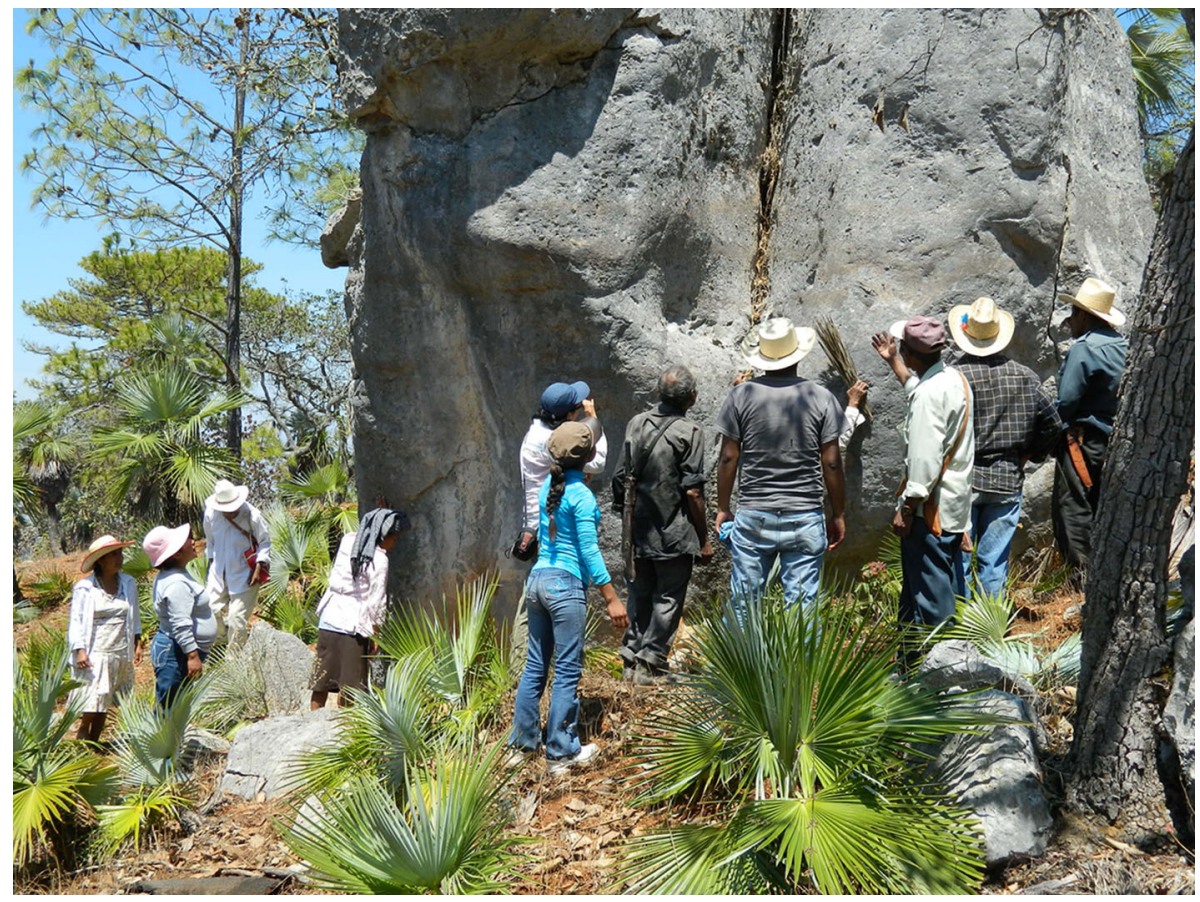

Fig. 3 Observation of the signals that the Rain god provides for the next rainy season

In the case of the Vehe Davu, containing stalagmites, the smoke of copal and the heat generated by the fire recreate the formation of clouds filled with water, falling in the form of rain. These first drops of water are the manifestation of the divinity itself, thus they are considered sacred, curative, and purify the body; the participants collect them and take them home as evidence of the divine act.

In turn, these drops are a sign of the upcoming rainy season that the wise ones know how to read and predict how will be the next rainy season, in other words, the marduma davu hear what Davu expresses. For the Vehe Davu that is at the summit, the signal for the rainy season is the presence or absence of a guide or pumpkin blossom in the rock, which like the drops, bear a sacred value at this time (Fig. 3).

The offering to Davu consists of seven bundles, each containing a dry leaf of corn that wraps a couple of small tortillas — one with beans and the other with chili-a piece of raw poultry (the head and the viscera are reserved for the main $\tilde{N} u h u$ ), a flower bouquet named in Mixtec ita пии ita (flower of flowers) and a candle. These bundles are placed in the seven plates that each Vehe Davu has (Fig. 4).

With regard to Davu (the Rain God), the shapes it takes in the interior of its House are diverse, can appear human and be in pairs (man and woman) or individually, or take the figure of some animal. The stalagmites are the result of the eternal Rain within the caves and, as a result of this formations, other forms that are seen as part of the House (doors, tables, chairs, pillars, pots and plates, among others) are considered the work of the divinity itself and therefore also sacred (Fig. 4).

In this sacred atmosphere the gathering occurs between the congregation and Davu (the Rain God): the marduma davu starts with the petition, gives a speech at the time he places 

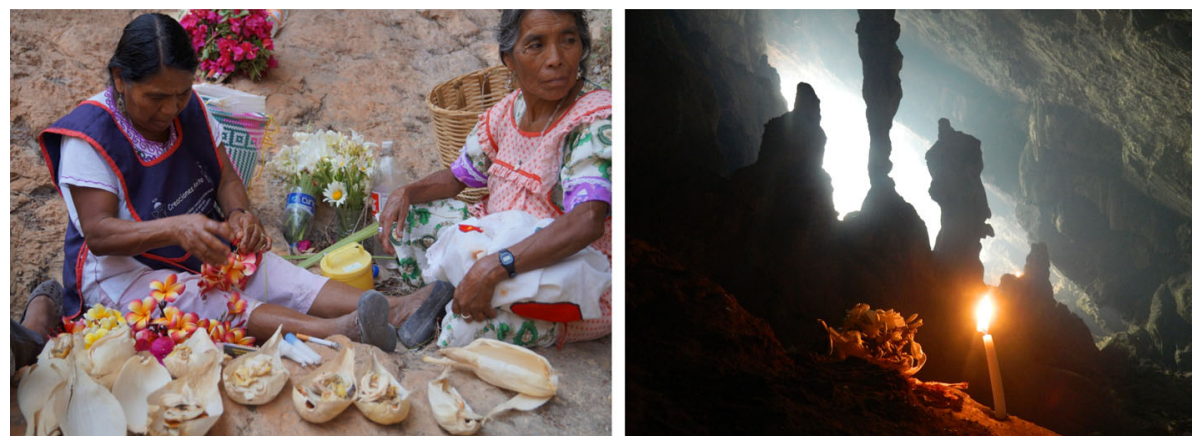

Fig. 4 To the left the preparation of the offering served to the Rain god. To the right in the foreground, one of the seven bundles that are part of the offering served in a plate of the House. In the background is the Rain god manifested in the stalactites

the bundles and offers pulque (beverage made from maguey), while others smoke the copal and ignite candles, likewise the rest of the participants we all join the petition and the gathering.

We all drink and share cigars with the Rain God while we offer our thanks and petitions, since besides the rain (arriving on time, sufficiently, without storm) and what it means in relation to the livelihood (to irrigate the crops, to green the hills, to nurture animals, etc.), through this ritual one asks for his own needs relating to the welfare of family and community, as well as for certain personal concerns, such as having the gift to heal, being a good rider or hunter, and having children.

The marduma also carries food for the participants; this consists of tortillas-normal size-some smeared with beans and others with chili, a piece of chicken and drink; in a certain way the same thing offered to Davu. It is a significant food that we all share in the gathering, therefore it is considered sacred and those who eat it are part of this unique and supreme moment shared with the divinity itself.

This gathering is the climax of the ritual, because it is when we participate in the sacred and reach the communitas ${ }^{10}$ (physical, mental and spiritual change that every participant experiences in relation to the others). Thus, during the gathering in the Vehe Davu, each participant undergoes a change reflected during the return and upon arrival to the house of the marduma.

The closure of the ritual consists in the reception of the pilgrims at the house of the marduma davu; each participant gets a necklace made of Flower of May and a hand greeting accompanied with the expression tauko Davu (welcome Rain). At that time, we (the authors) understood the meaning of ritual, we had been in the Vehe Davu in a gathering with the divinity, and by doing so we were infused with the sacredness and qualities of Rain, as this is the profound change that each participant experiences during the ritual in the Vehe Davu.

Therefore the importance of the return of the people, since all the participants, in a figurative sense, undertake the way back in form of Rain and this is a metaphor of how the

\footnotetext{
10 This condition of communitas that is achieved in a shared way in the ritual allows you to experience a feeling of total unit, starting from oneself, with the congregation, with the universe and being in this communion, to form part of the divine. Under this condition social status and everyday life experience are dismantled, any distinction dissolves and it can even change the identity of the participants themselves (Rappaport 2001).
} 
coming rainy season will be, i.e. if the pilgrims are careless and come back fast, the rains will be storms, on the contrary, if they return in calm, the rains will be suitable for crops. It is a way of giving substance to the rain. Finally, there is a shared last meal and the ritual success, the fine arrival and the fulfillment of the commitment to go to bring Rain are celebrated.

Thus, the importance of this ritual lies in the recognition of water as a sacred being for the continuity of life itself, i.e. Davu (the Rain God) and the restoration of its dwelling as a sacred place, the Vehe Davu (House of the Rain God). Beyond the call made to the Rain, is the thought that human beings are part of a much larger mesh and share this world with sacred beings, which like us, have their unique way of being alive and follow their own rhythms, making the flow of the world possible.

It is relevant to mention that the $\tilde{N} u u$ Savi (People of the Rain) has held their beliefs because they share a sacred perception of the landscape. Additionally, they have effectively incorporated into their traditions, elements from outside that sometimes have been by choice and many others by violent imposition. It has been an active persistence to different process such as colonial, Mexican State and globalization that have imposed their models over the worldview of Mesoamerican Peoples through time.

With regard to the Vehe Davu (House of the Rain God), we can say that this concept refers to a specific place where the Rain God becomes present in the form of a sacred rain that occurs during the ritual. This dwelling is perceived as a place in continuous and active growth, i.e. alive. It is also important to emphasize that these places are sanctuaries in its broadest sense, since they are visited with different purposes on different days of the year, they are mainly places of healing, or learning to heal, some are also places to make requests.

In regard to $D a v u$, we understand that referring to this deity is to consider, in an integral manner, different sacred elements that are also part of the landscape, as springs, clouds, wind, lightning, thunder, haze, humidity and rain drops.

\section{The negative perception of the Vehe Davu in the colonial period}

Currently, the aforementioned ritual, the people who made them, and the sacred places are disqualified by outsiders of this cultural tradition. This thinking has its origins in Mexico's colonial period (1521), when the Spanish regime was established and with it, the violent imposition of Christianity as the sole religion.

The spiritual conquest had as its main objective the goal of putting an end to all the religious expressions and the religion itself, although it was not fully achieved. The colonization was a long, painful and complex process for the civilizations of Mesoamerica and $\tilde{N} u u$ Savi, which remains in effect today when the image of the colonized is recreated (Memmi 2003).

Around 1570, Fray Bernardino de Sahagún wrote a compendium of 12 books on the Nahuatl region in the center of Mexico, a monumental work that sought to know the different cultural and religious manifestations in order to exterminate them. This idea is mentioned in its foreword when it, first, compares the medic with the clerics and, second, the disease with the Mesoamerican religion, called contemptuously idolatry or matters of the devil. He also mentions that the clergy are medics of souls and they heal the spiritual illnesses of the innocent, which have to be cured and exterminated (Sahagún 1998).

The idea of extermination and disqualification toward the Mesoamerican religion is present in many of the colonial documents, therefore they must be taken with a critical 
sense yet, paradoxically, they are the most direct source of information that we have on this religion. This allows us to make a historical study on the perception of water and rain as well as of its loss of value.

Focusing on the colonial records documented about the Rain God in the Mixteca region, i.e. Dzavui, ${ }^{11}$ they show his importance as one of the main gods: invoked not only when there was a shortage of water, in times of drought, but also when there was illness or when it was time to harvest; these ceremonies were carried out throughout the year (Terraciano 2013).

For the Nahuatl region, Sahagún mentions...

...that this god called Tlaloc Tlamacazqui was the Rain God, they understood that he gave rain to water the earth, through this rain all herbs, trees and fruits and nourishment were bred. They also understood that he sent hail and lightning and rays and the storms of water and the dangers of the rivers and the sea... he gives men the nourishment required for bodily life (Sahagún 1998).

Rituals to the Rain God were banned during the colonial period, and if any person made such actions, it was severely punished by the Holy Inquisition (Sepúlveda y Herrera 1999; Terraciano 2013). The sacred places where these rituals were performed were located at the center and in the surroundings of the populations (Sepúlveda y Herrera 1999; Terraciano 2013). It should be noted that as the first years of the colonial period went by, the temples located within the population were completely destroyed and instead, churches or huahui ñuhu (Sacred Houses) were built, as a symbol of the new power and the imposition of a new religion (Terraciano 2013).

The sanctuaries in the vicinity of the community were not physically destroyed because they were not located within the confines of the community, they were countless, and only the inhabitants knew about them and went unnoticed by the Spanish as they comprised natural temples. We speculate these are some of the reasons why rituals dedicated to Dzavui survived in sanctuaries as caves, mountain tops, rocks, springs or rocky shelters.

In relation to this type of sanctuaries dedicated to Dzavui, Fray Francisco de Burgoa provides a detailed description of a cave in the Mixtec that allows us to know its composition and relate it to the sanctuaries of today, it is located in the contemporary community of San Miguel in Juxtlahuaca:

...one enters through a door with an arc shape, of more than 25 canes high, and 10 of width, leaving the narrow body of its waters, almost four canes wide at each side, and inside you discover a dome so high that exceeds by much the door, and close to it on the left hand side was a plinth of marble forged there, and on it a great figure in costume, and garments of apostle, or prophet, with the mantle over the head, the face discovered and the hands placed accordingly, and all of one piece as if it was poured: from the roof of the whole cave hung, of the same metal, a multitude of diverse animals, large and small, and some with remarkable perfection, one could recognize even the smallest limbs... but what caused admiration in this cave, was to see that from an indifferent and vague drop of water on the run several figures are formed, and distilling so small, they gave body to statues, figures and animals as different... and where the admiration of the most attentive judgments was able to reach, is in $a$ half circle stack, as of holy water that is on the right side of a canvas,... and the water

11 Dzavui (the Rain God) refers to the colonial period, corresponds to Davu in the dialectal variant of Yuta Nduchi. In this section, we use the terms in Mixtec that are found in the colonial documents. The term that remains unchanged is Vehe Davu (House of the Rain god). 
that fills it, distills from the edge of the rock, being the matter which formed it, leaving it perfect, it was always full and overflowing,... when I saw it I considered the work very slowly, it tore my heart apart to see how empowered of this land the demon was because he so slowly built his house;... about two blocks you can walk with clarity, and then comes the dark, and gloomy, along the way of the creek, to rocky, and narrow impossible to walk, and goes under the hill with a great grove that covers it above, and breathes the flow of water,... and the prince of darkness used everything to hides this infernal burrow, for over 80 years, coming from far away, from many nations to sacrifice the God of the sacrilegious Synagogue, and 46 years ago Our Lord was interested in having indians of good descent, so the place was declared to the religious,... the cave was blessed, and the demons expelled: crosses with many verses, and devout written prayers were placed, and religious people continue to visit it (Burgoa 1989). ${ }^{12}$

Based on Burgoa's description of the cave, there is no doubt that it is a Vehe Davu (House of the Rain God). It is interesting to notice that the friar's perceptions on this sacred place is directly related to his own experience within the Houses of the Rain God. After visiting several of these places with people who carried out the ritual, his participation showed him what was sacred to them, what they perceived as a sanctuary, and that he understood its significance.

Burgoa's insight is evident when he mentions that water is integral to the sanctuary, as well as the animals and statues, not to mention the "apostle" or "prophet", which was undoubtedly the Rain God, in addition to noting that the water distilled from the edge of the rock was blessed. We saw both perceptions during the ritual in the community of Yuta Nduchi.

In the same way, his Christian orientation is reflected in the use of words such as arcs, high domes, apostle or prophet. The comparison between the Vehe Davu and the church tells us of the admiration and impact the friar had for this type of sanctuary. It must be remembered that during this time, Catholic rituals in Europe were carried out in churches, i.e., in constructed buildings more than in natural places. This spiritual outlook of the colonizers disqualified this complex ritual of the Rain God using pejorative terms and ideas, such as the sacrifice of children, a very recurrent theme in other colonial documents (Sahagún 1998; Sepúlveda y Herrera 1999).

The ideological destruction was also part of the colonial process, during which time the image of the Vehe Davu (House of the Rain God) was deemed as "places of the devil", portraying Dzavui (Rain god) as the "devil", and rituals as "rites to this evil being".

A portrayal of this harrowing process was embodied in the open chapel of Actopan in Hidalgo, which displays how the concepts of sin and hell were imposed on Mesoamerican rituals and deities. In this sense, the use of hell in evangelization was part of the strategy of subordination; it worked as an ideological complement to the process of conquest of people reluctant to accept the European models (Vergara Hernández 2008).

Within the complex narrative that this mural painting expresses there is a scene of interest for the topic that concerns us, the Vehe Davu (House of the Rain God). That is the jaws of the Leviathan represent a symbol of the gateway to hell where, according to the narrative, the indigenous inhabitants who continue to perform their rituals and exerting the Mesoamerican religion will end.

12 Highlighted words are ours. 
In this mural, the Leviathan is a large reptile covered with quills, with an open muzzle and baring large and sharp fangs. Near his nose a devil appears with a lashing tongue and large glasses, carrying a key in his left hand, confirming the role of the jaws of the Leviathan as the entrance to hell (Vergara Hernández 2008) (Fig. 5). As Jansen and Pérez (2015) pointed out, in this devil figure iconographic characteristics of the precolonial Rain God are displayed.

We can also add that under the precolonial Mesoamerican worldview, as we will see later, the native population could understand the fangs of the Leviathan as a sanctuary dedicated precisely to this divinity of the Rain, i.e. a Vehe Davu. We then see that this sacred enclosure, in the case of this mural, is associated with hell itself.

In the mind of Christian religious zealotry, the conquest of these lands and their struggle to teach the gospel were not against another religion but against the demon, and so was it recorded in their chronicles (Romero Frizzi 2008). In this regard, it should be noticed that the friars who came to Mexico brought a tradition of eradication of "witchcraft" from Europe, where through the "Holy Inquisition" thousands and thousands of midwives and women healers were killed because of the hunting of "witches". It was with this obsession and desire to impose their vision that the friars and Spaniards arrived in Mesoamerica (Jansen and Pérez 2015).

In the imaginary of medieval Europe, witches were specialists in killing and eating new born children during their ceremonies, considered by the friars to be anti-Christian (Cohn 2005). Even Christianity suffered this disqualification in its beginnings, when Romans said that Christians had meetings in which children were ritually slaughtered and festivities in which the remains of these victims were ritually devoured (Cohn 2005). Ironically, as
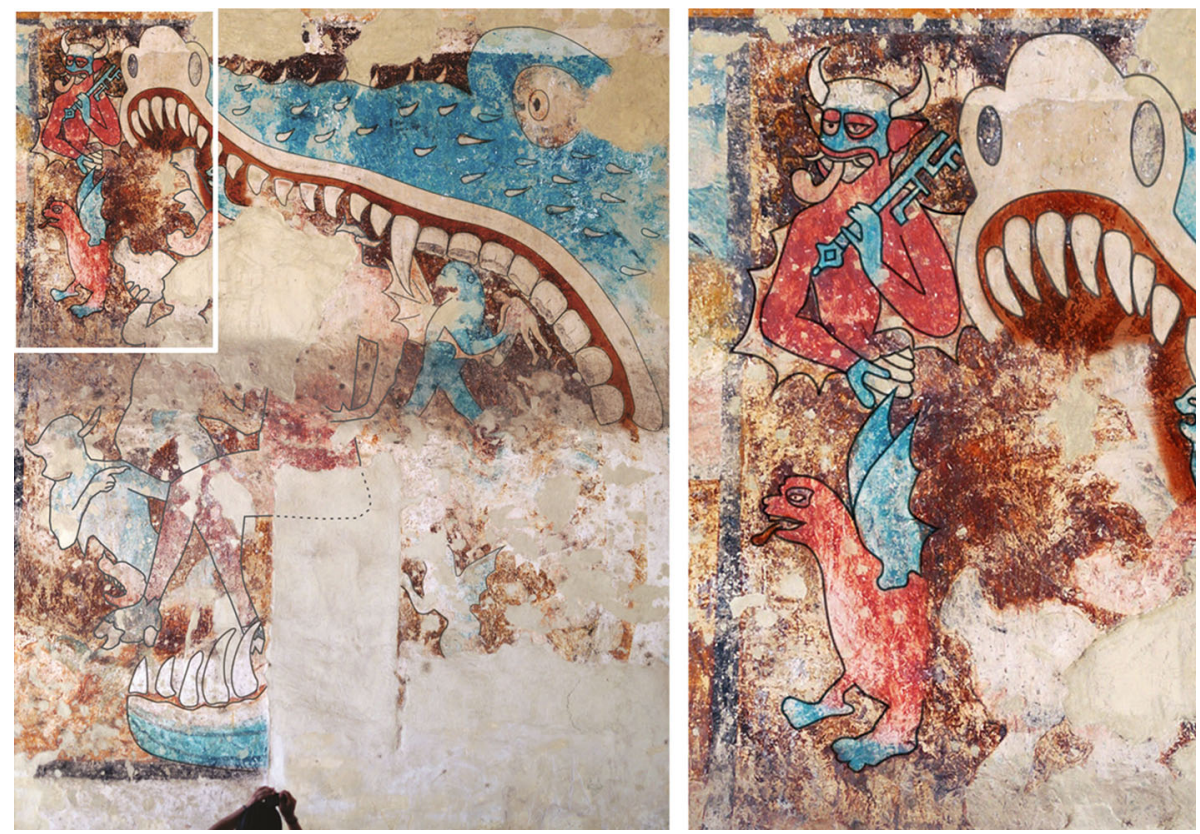

Fig. 5 Murals of the open chapel of Actopan in Hidalgo, as part of the colonial imaginary the demon is shown with characteristics of the Rain god and the fangs of the Leviathan as a House of the Rain God 
mentioned, those same prejudices and ideas of human sacrifice were transferred to the complex of the Rain God by the conquerors and friars throughout Mesoamerica.

\section{Representation of the Vehe Davu in precolonial times}

Much of what is known about the Rain God in precolonial times is due to the archaeological research carried out in the Templo Mayor of Mexico Tenochtitlan, religious and political center of the Mexica (Matos Moctezuma 1986). This sanctuary was formed by a double temple, the south side of which is dedicated to Huitzilopochtli (the Warrior God), and the north side to Tlaloc (the Rain God). Interestingly, with an astronomical orientation toward the Tlaloc hill (Aveni et al. 1988), in this temple archaeological excavations reveal multiple offerings related to this god (Broda 1982; López Lujan 1993), which speaks of its importance during that period (1200-1521 A.D.).

Through the aid of archaeological research, we know the characteristic aspects of the Rain God: his face bears a resemblance of glasses, a screwed nose, tusks, and sometimes, a mustache; his body is painted blue or black; he commonly carries in one hand two intertwined snakes symbolizing lightning and in the other, a jar with water; decorated with, among other things, tender plants of corn and representations of hills (Solís 2001; Fundación Cultural Armella 2008) (Fig. 6).

The Rain God is one of the most representative of Mesoamerica with clear iconographic elements, which makes it easy to identify both in space and time (Solís 2001). Its presence was identified since early times (1500 B.C.) (Broda 1971; Olivier 2009); but it was during the era of Teotihuacan (100-900 A.D.) that it took on the characteristics described above (Solís 2001).

In the Highland Mixtec region there are multiple representations and references of Savi (the Rain God): one of the earliest (400 B.C.) is the stela of Yuku Ita (Cruz Castillo 2007; Rivera Guzmán 2008), as well as a sculpture in the precolonial settlement of Huamelulpan. As one of the most important sites of the region, inhabited between 500 and 900 A.D. (Spores 1972; Caso 2003), it currently has the name of Yuku Ñu Dahui (Hill of the Rain God). Also, just before the arrival of colonizers in 1521, in the settlement of Yuku Ndaa, there was a precinct decorated with sculptures of characters dressed with the attributes of Savi, related with corn and the royalty (Diego Luna 2014); this divinity is also present in several codices.

Thus, with archaeological elements and with precolonial documents (codices) we know that the Rain God was not only related to agriculture or the nourishment of human beings, but also influenced other aspects of daily life. We see an example of this on page 23 of the Laud codex, where he is represented as Lord of the days (Anders and Jansen 1994) (Fig. 6).

As shown, several aspects of the Rain God are known but little has been said of his sanctuary, the House of the Rain God, however, thanks to the current experience in the ritual and what is described in the historical sources, we can understand how these places were perceived and know the signs of this divinity. There are several examples of the House of the Rain God in precolonial times; in this paper we focus on the relief of El Rey located on the site of Chalcatzingo since it best expresses this concept. Additionally, it will allow us to draw a comparison with what is described in the colonial painting of the open chapel of Actopan. 


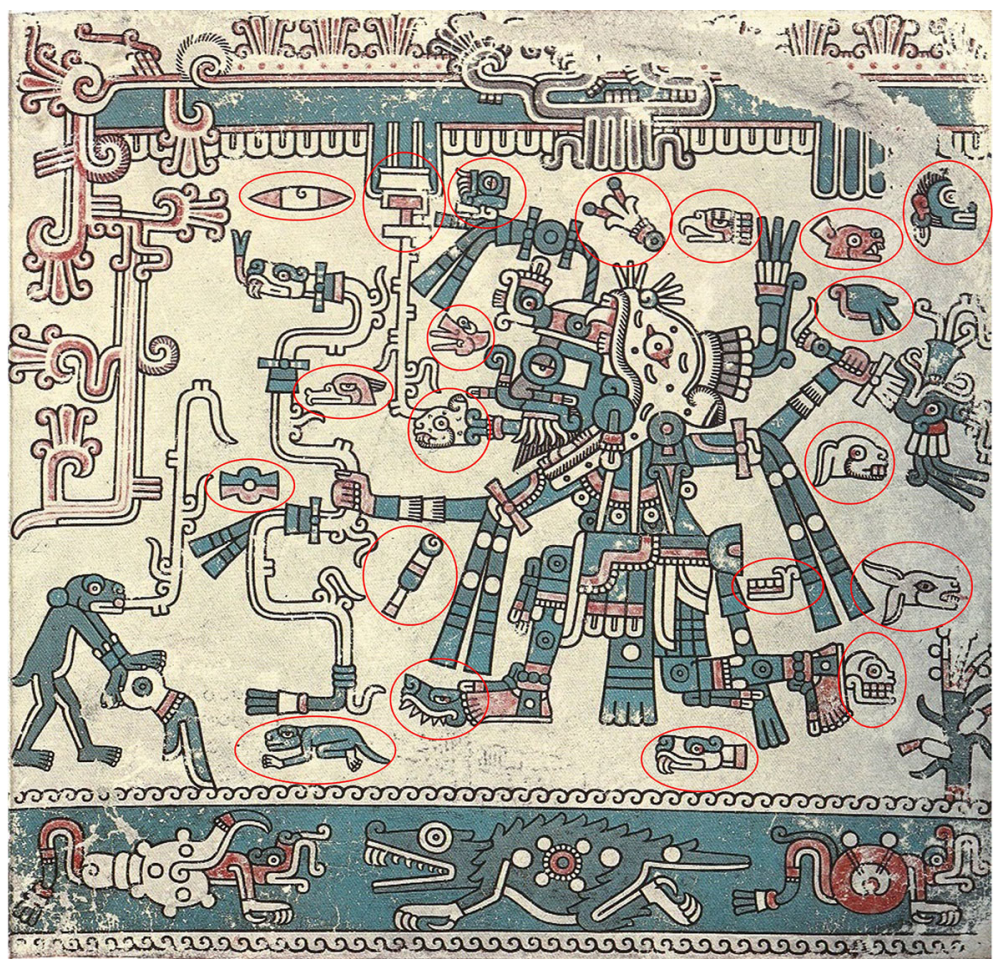

Fig. 6 The great Rain God, which walks under the clouds, brandishing its ax and its serpents which are the thunders and clouds, walks above the sea where such animals as the alligators live. It determines the destiny of the days represented by symbols around it: alligator, wind, house, lizard, serpent, death, dear, rabbit, water, dog, monkey, grass, reed, jaguar, eagle, vulture, movement, flint, rain and flower (Anders and Jansen 1994)

The millenary sanctuary of Chalcatzingo is made up of two impressive twin mountains located in the valley of the river Amatzinac and the precolonial settlement is located at the foot of these, in the state of Morelos. Archaeological projects in the area have revealed that this place was inhabited for the first time in 1400 B.c. and after some centuries became one of the main centers of the Preclassic era in the plateau and reached its peak between 700 and 500 в.C. (Grove 2010). There is also evidence of pilgrimages to Chalcatzingo made from early times and until later times (Grove and Angulo 1987).

This settlement is mainly known for its extraordinary monuments carved in stone registering central concepts of thought and religion in Mesoamerica. The monuments of interest for our topic are six bas-reliefs carved in the walls of the Chalcatzingo Hill that are located next to a canyon where rainwater drains. These reliefs should not be seen individually but as a pictorial sequence, the earliest in Mesoamerica (Angulo 1987).

The first five reliefs are small and each one presents an animal with the head up and with a bifurcated volute leaving its mouth directed toward the clouds, whence raindrops fall. Also present is the motif of the horizontal S that serves as the basis for these figures. Under three of these small animals there are flowering pumpkin plants.

The sixth bas-relief that gives closure to this narrative sequence is of greater dimensions (approximately $3 \mathrm{~m}$ by $3 \mathrm{~m}$ ), and is known as "El Rey", a name given by residents referring to the character who is sitting in a large niche, which is the central part of the 
scene. The niche is formed by a mountain motif that at the same time is the profile face of a snake; his open mouth is understood as the cave of the mountain (Grove and Angulo 1987). This place where the divinity resides, in Mixtec terms, is a Vehe N $u h u$ (House of God) (Fig. 7).

In the interior of this cave is "El Rey" sitting on a rectangular block that contains the symbol of the horizontal S, seen before at the base of the animals, holding a similar object in his arms. This god is lavishly dressed, and excels in its headdress with motifs of corn plant. It is noteworthy that both he and his clothing are decorated with drops of rain (Angulo 1987; Grove and Angulo 1987) (Fig. 7).

From the mouth of the cave, large volutes leave in various directions, as if describing a torrent of wind. On the mouth, on the outer edge, there are plants similar to those that grow in the rocks of the hill itself. Completing this scene, above the niche there are three clouds filled with water from which drops of rain fall; below the clouds there is abundant rain and also chalchihuitl glyphs (jade stones) (Angulo 1987).

With this description, we see that the relief of El Rey features several elements that we saw in the current ritual of Bringing the Rain, which allows us to consider it as a House of Rain, these are:

(1) The reference to the interior of a cave, usually associated to a mountain, as House of the Rain god.
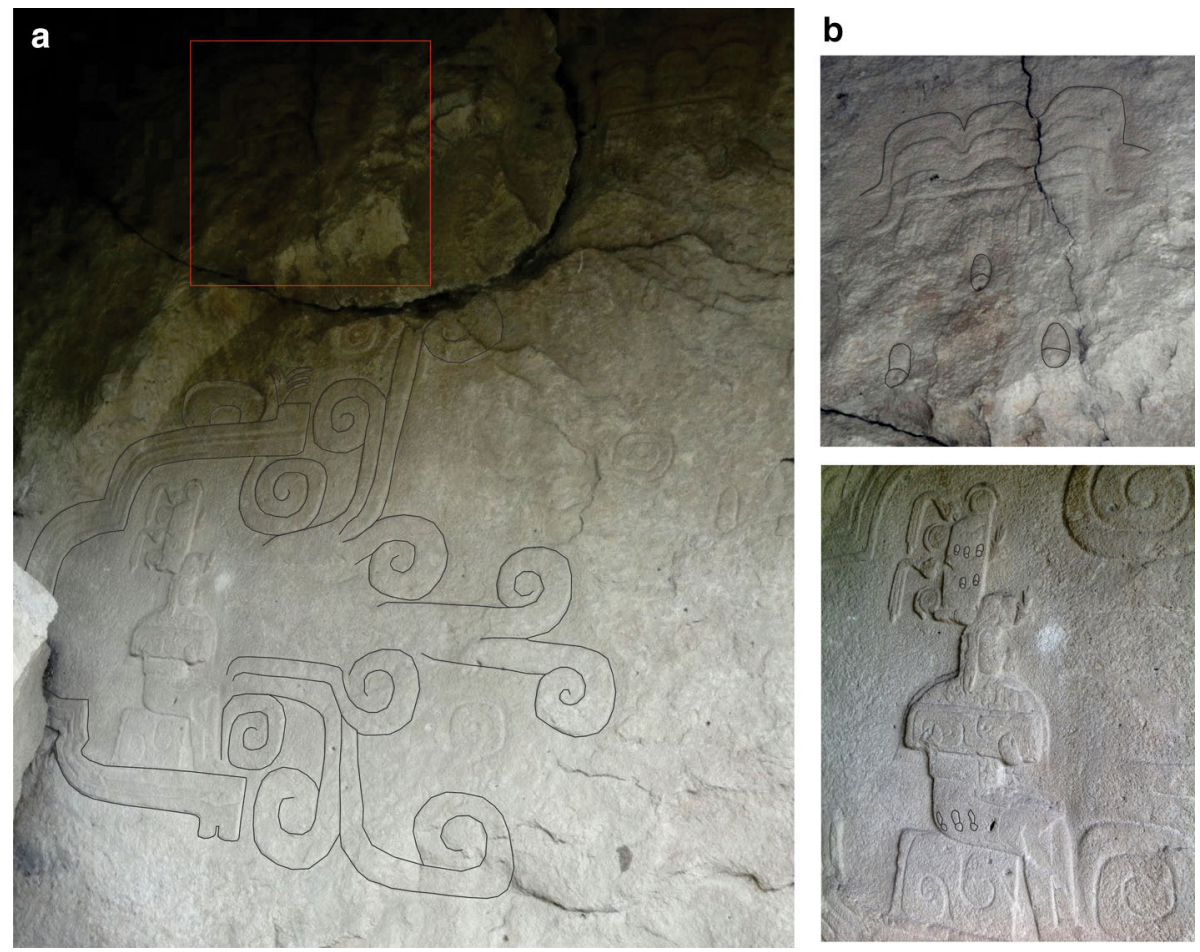

Fig. 7 Relief of "El Rey" in Chalcatzingo, Morelos. a Drops of rain falling from the clouds and $\mathbf{b}$ Rain god with drops in his clothing 
(2) The importance of the wind for the formation of clouds filled with water from where drops of rain fall. In the current ritual, a path of flowers is laid down to direct the rain toward the community.

(3) The drops of rain, which in this ritual context are considered sacred and curative, are a manifestation of the divinity itself that at the same time give it form and substance. In the relief of "El Rey", it should be noted that the character carries drops of rain in both his headdress as in his clothing, symbols that highlight his quality of Rain. We consider that this representation refers to the materialization of the divinity from the sacred rain itself that happens during the ritual, as it occurs with the formation of stalactites.

(4) The presence of sacred plants such as corn and pumpkin, fruits of Mother Earth that are the main livelihood of the people, and in the same way, in its ritual context, could be understood as the signals of the rainy season to come.

(5) The representation of the sons of the Rain God, who announce and bring the rains, which in the case of the relief, are the animals that participate in the ritual. In a metaphorical sense they are the marduma davu (head for the celebration to the Rain god), who currently make this request and bring the Rain.

Thus we consider that the central character of the relief is the Rain God and what we are seeing in this pictorial scene could be the representation of a fundamental sequence of the ritual of Bringing the Rain, not any rain though, but the sacred Rain that occurs only during the ritual, in the presence of the divinity, experienced by the entire congregation gathered there.

This narrative was inscribed approximately 3200 years ago and it should be noted that, today, one of the festivities of Chalcatzingo is the celebration of the Holy Cross on May 3, i.e., the Bringing the Rain. The people visit the Cross erected at the top of the mountain and leave offerings (Carolina Meza Rodriguez, the manager of the archaeological site, personal communication 2015).

\section{Final considerations}

From the foregoing, by integrating experiences in the current rituals of bringing the rain with colonial and precolonial records, we succeeded in following the indigenous histories of water in Mesoamerica, particularly of Nuu Savi (People of the Rain). We focused on these three moments on time because each one provides specific information about the sacredness of the water.

For example, with our involvement in the ritual of bringing the rain performed at present in the community of Yuta Nduchi we learned the structure and the sequence of the ritual itself, also with these experiences we understood the Rain God and his dwelling. During colonial period there was a clear intention of extermination and disqualification toward the Mesoamerican religion that was recorded in the documents and in some murals. As a result, many Houses of the Rain God were destroyed and others, due to the importance for the ancient inhabitants, were blessed by the friars. This fact gave to these sacred places part of the Christian symbolism that, together with the Mesoamerican symbolism, resulted in the synergy that is experienced currently in the ritual.

In the other hand, the influence of the Rain God in different domains of life had its splendor during precolonial times and the Houses of the Rain God (built and natural) existed throughout Mesoamerica, as shown by the precolonial documents and the artistic 
expressions (codices, sculptures and reliefs). The importance of these Mesoamerican components (the Rain God and his house) was such that determined: the orientation of large cities as Tenochtitlan, the built of important ceremonial and political precincts like that of Yuku Ndaa, the pilgrimages to regional sanctuaries such as Chalcatzingo, and the very life of the Mesoamerican that was influenced by the days of the calendar, as expressed in the ancient books.

The implementation of the approaches of the landscape study and living archaeology, both complementary, allowed us to integrate the different data (current knowledge, colonial and precolonial) and to understand them as part of Mesoamerican cultural continuity.

Therefore, integrating information from these three moments, we recognize that the perception and characteristics of the water as a sacred being have not remained static, because in each moment has adhered and removed part of its symbolism, however the link that unifies these three moments is that the Rain God and his dwelling have been a constant in Mesoamerican religion through time.

It is also clear that there have been changes; one of these is that the temples dedicated to the Rain God no longer reside in the central part of the communities and only some of the natural temples of the surroundings continue. Additionally, the iconographic elements that characterized the god in precolonial times are no longer present; however, his perception and conceptualization have been incorporated, by way of synergy, in the image of different Catholic Saints referred to, individually, as our Rain Lord or The Saint of the Rain.

With these remarks, it is not intended to reflect a current dual reality about what continues and what has changed since precolonial times, but instead to refer to a situation where there is a link between present and past, in this case on the understanding of the Rain God and his dwelling. Similarly, we want to show that these elements of the Mixtec religion were and are an integral part of a larger narrative by being associated with the realization of rituals of bringing the rain, a fact that shows us a continuous experience in the landscape.

Thereby, the persistence of the perception about water among the indigenous peoples of $\tilde{N} u u$ Savi is mainly because it is based on philosophical and religious foundations that arise from the individual and the collective experience in a shared landscape with other beings, and that has been effective through time i.e. water has always had an active presence in interaction with beings (human and no human) that influence on the flow of the life itself.

Finally, with this research we understood that through the study of the landscape is possible to follow different histories of life, as we exemplified with the history of the Rain God from precolonial times until today. According to the perception of the Nuu Savi People this God has participated in the making of the landscape, fostering the growing of vegetation and crops, feeding animals and humans beings, and creating his own dwelling (the House of the Rain God) with the eternal drops that sprout in these sacred places.

The contemporary and past generations have also participated in the making of the Houses of the Rain God (at the physical and symbolic level) with the different relationships they have established with these places, as sacredness, destruction, blessing, demonization and curiosity. These relationships have been recorded in different documents as well as in the sanctuaries that are part of the landscape, in this sense, the three moments aforementioned (actual, colonial and precolonial) are embodied in the landscape. Thus, we consider that the landscape is a tangible record of the becoming, and it offers a great opportunity to link present and past with a dynamic approach that shows the changes and continuities. 
In regard to water, the recognition of the Rain god and his dwelling is essential since, as a consequence of colonization, some Houses of the Rain God are currently referred to as places of the devil and there is a disdain for people who come to these sacred places and perform rituals. Similarly, the lack of understanding and insensitivity on the part of some researchers, not to mention main stream societies, who are outsiders to this cultural tradition, demean them with pejorative value judgments. In this regard, we must be aware that this attitude damages and limits the personal development and prevents, in some way, the full freedom to live in the ancestral landscape, which we referred to at the beginning.

It is important to take into consideration this knowledge about water as a being who gives life, and not only as a resource consisting of two hydrogen and one oxygen atom $\left(\mathrm{H}_{2} \mathrm{O}\right)$ ideally suited to be exploited. The perception of water as a being will allow us to have a relationship of respect and concern regarding it, which will improve our life as inhabitants of the world.

Thus, this historical study of water as a sacred being is directed to a recognition and respect of the Mesoamerican-Catholic religion and of a free life for the indigenous peoples in an ancient and contemporary landscape.

Acknowledgments The research that produced the result that is presented here is a part of the project 'Time in intercultural context', directed by Prof. Dr. Maarten E.R.G.N. Jansen (Faculty of Archeology, University of Leiden, Netherlands), and has received financial support from the Seventh Framework Program of the European Union (FP7/2007-2013) under the Grant agreement No. 295434. We are deeply grateful to the authorities of Yuta Nduchi, Oaxaca as well as to all the people who have shared their knowledge and have supported us in the realization of our work and in particular, for the subject that we discuss here, to the marduma Davu (Head for the celebration to the Rain god).

Open Access This article is distributed under the terms of the Creative Commons Attribution 4.0 International License (http://creativecommons.org/licenses/by/4.0/), which permits unrestricted use, distribution, and reproduction in any medium, provided you give appropriate credit to the original author(s) and the source, provide a link to the Creative Commons license, and indicate if changes were made.

\section{References}

Anders F, Jansen M (1994) La pintura de la muerte y de los destinos. Libro explicativo del llamado Códice Laud, 1st edn. Fondo de Cultura Económica, México

Angulo VJ (1987) The Chalcatzingo reliefs: an iconographic analysis. In: Grove DC (ed) Ancient Chalcatzingo. University of Texas Press, Austin, pp 132-158

Aveni AF, Calnek EE, Hartung H (1988) Myth, environment, and the orientation of the Templo Mayor of Tenochtitlan. Am Antiq 53(2):287-309

Barabas AM, Bartolomé MA, Castillo Cisneros MC, Lechner Edelkind DL, Moreno Moncayo N, Oliveras Ita D (2010) La Danza del viento y de la lluvia. Un ritual agrario en la Mixteca de Oaxaca. In: Barabas AM, Bartolomé MA (eds) Dinámicas culturales. Religiones y migración en Oaxaca, México, pp. $175-250$

Broda J (1971) Las fiestas aztecas de los dioses de la lluvia. Revista española de antropología americana $6: 245-327$

Broda J (1982) El culto mexica de los cerros y del agua. Multidisciplina 7:45-56

Burgoa FFd (1989) Geográfica descripción de la parte septentrional del Polo Ártico de la América y, nueva iglesia de las Indias Occidentales, y sitio astronómico de esta provincia de predicadores de Antequera Valle de Oaxaca, 1st edn. Porrúa, México

Caso A (2003) Exploraciones en Oaxaca. V y VI Temporada 1936-1937. Alfonso Caso, Obras 3: El México Antiguo (Mixtecas y Zapotecas). El Colegio Nacional, México, 3:3-146

Cohn N (2005) Europe's inner demons The demonization of christians in medieval chrisendom, 2 nd edn. Pimlico, London

Cruz Castillo ON (2007) La estela 1 de Yucuita, Oaxaca. In: Spores R (ed) La evolución de la cultura mixteca desde los primeros pueblos preclásicos hasta la independencia . IEEPO, Oaxaca, pp. 455-462 
Diego Luna L (2014) Ritualidad y poder: los relieves del Aniñe (Palacio) de Yucundaa. Maestría, Univesidad Nacional Autónoma de México (UNAM), Pueblo Viejo de Teposcolula

Fundación Cultural Armella (2008) Tláloc El que hace brotar la lluvia. CACCIANI, México, D.F

Grove DC (2010) Chalcatzingo: Breve introducción. Traducción de Chalcatzingo: a brief introduction. www.mesoweb.com/pari/publications/journal/901/Chalcatzingo.pdf

Grove DC, Angulo J (1987) A catalog and description of chalcatzingo's monuments. In: Grove DC (ed) Ancient chalcatzingo. University of Texas Press, Austin

Ingold T (2000) The perception of the environment. Essays on livelihood, dwelling and skill. Routledge, London

Ingold T (2011) Being alive. Essays on movement, knowledge and description, Routledge, 1st edn. Taylor and Francis Group, London

Ingold T (2013) Dreaming of dragons: on the imagination of real life. J R Anthropol Inst 19:734-752

Jansen MERGN (2004) Archaeology and indigenous peoples: attitudes towards power in ancient Oaxaca. In: Bintliff J (ed) A companion to archaeology. Blackwell Publishers, Malden, pp 235-252

Jansen MERGN (2008) Social and religious concepts in Nuu Dzaui visual art. Mixtec writing and society. In: van Broekhoven LNK (ed) Escritura de Ñu Dzaui, Jansen ERGNM. KNAW Press, Amsterdam, pp 187-215

Jansen MERGN, Pérez JGA (2008) Paisajes sagrados: códices y arqueología de Nuu Dzaui. In: Itinerarios, pp 83-112

Jansen MERGN, Pérez JGA (2015) Tiempo, religión e interculturalidad en la colonia: los catecismos pictográficos de México. In: Jansen MERGN, Raffa V (eds) Herencias e interacciones socioculturales en Mesoamérica y Occidente, Holanda, Países Bajos

Jansen MERGN, Pérez JGA (2011) The Mixtec pictorial manuscripts. Time, agency and memory in ancient Mexico. BRILL, Boston

López Lujan L (1993) Las ofrendas del templo mayor de Tenochtitlan. INAH, México, D.F

Matos Moctezuma E (1986) Vida y muerte en el Templo Mayor. Ediciones Océano, México, D.F

Memmi A (2003) The colonizer and the colonized. Earthscan Publications, NewYork

Méndez Granados D (1999) Las ceremonias de petición de lluvia. In: Eroza Solana Enrique (ed) El agua en la cosmovisión y terapeutica de los pueblos indigenas de México, INI, México, pp. 15-37

Monaghan J (1995) The covenants with earth and rain. Exchange, sacrifice, and revelation in Mixtec Sociality, 1st edn. University of Oklahoma Press, Norman

Olivier G (2009) Tláloc, el antiguo dios de la lluvia y de la tierra en el centro de México. Arqueología Mexicana. Dioses de la lluvia. XVI:40-43

Pérez JGA (2008) Sahín Sáu. Curso de Lengua Mixteca (variante de Nuú Ndéyá). México Universidad de Leiden, CSEIIO, Secundarias Comunitarias Indígenas y CEDELIO, Oaxaca

Rappaport R (2001) Ritual y religión en la formación de la humanidad, 1st edn. Cambridge University Press, Cambridge

Rivera Guzmán ÁI (2008) Los inicios de la escritura en la Mixteca. Mixtec writing and society. In: Jansen MERGN, van Broekhoven LNK (eds) Escritura de Nuu Dzaui, KNAW Press, Amsterdam, pp. 109-144

Romero Frizzi MdlÁ (2008) Teposcolula. Aquellos días del siglo XVI. Dirección General de Culturas Populares del Consejo Nacional para la Cultura y las Artes, Oaxaca

Sahagún FBd (1998) Historia General de las cosas de Nueva España., 2nd edn. García Alfredo López Austin and Josefina

Sepúlveda y Herrera MT (1999) Procesos por idolatría al cacique, gobernadores y sacerdotes de Yanhuitlan, 1544-1546. Instituto Naccional de Antropología e Historia, México, D.F

Solís F (2001) El hombre frente a la naturaleza mítica. Dioses del México antiguo. In: Atlasbooks. México

Spores R (1972) An archaeological settlement survey of the Nochixtlan Valley, Oaxaca. Vanderbilt University, Nashville

Terraciano K (2013) Los mixtecos de la Oaxaca colonial. La historia Nudzahui del siglo XVI al XVIII, Fondo de Cultura Económica, 1st edn. (in Spanish)

Vergara Hernández A (2008). El infierno en la pintura mural agustina del siglo XVI. Actopan y Xoxoteco en el estado de Hidalgo. Universidad Autónoma del Estado de Hidalgo. Instituto de Artes, Hidalgo, 1st edn. p 217 